\title{
FIRST REPORT OF BIG ONION FLOWER MOLD CAUSED BY Aspergillus niger on Allium cepa L. in SRI LANKA
}

\author{
W.M.K. Fernando ${ }^{1 *}$, R.S.W. Wijeratnam², D.M.J.B. Senanayaka ${ }^{3}$, C.M. \\ Nanayakkara $^{4}$, W.A.R. Dhammika ${ }^{1}$, W.M.W. Weerakoon ${ }^{5}$, A.M.Perera ${ }^{1}$, W.M.S.D.K. \\ Wijerathna ${ }^{1}$ and D.M.K. Dissanayake ${ }^{1}$ \\ ${ }^{1}$ Field Crops Research and Development Institute, Department of Agriculture, Sri Lanka \\ ${ }^{2}$ Industrial Technology Institute, Colombo, Sri Lanka \\ ${ }^{3}$ Rice Research and Development Institute, Department of Agriculture, Sri Lanka \\ ${ }^{4}$ Faculty of Sciences, University of Colombo, Sri Lanka \\ ${ }^{5}$ Department of Agriculture, Sri Lanka
}

\begin{abstract}
Big onion is a main cash crop grown in Sri Lanka. However, the crop is highly susceptible to diseases: anthracnose, purple blotch, bulb rot and black mold. Although black mold disease symptoms are associated with the onion bulb, black moldy growth on onion flowers has been observed to be spreading in Sri Lanka during the last decade resulting in the reduction of quantity and quality of onion seeds. Hence, this study was conducted with the objective of isolation and identification of causal agents of the onion flower mold. Big onion flower samples with mold symptoms were collected during Maha season 2016/17 from the major onion growing areas of Anuradhapura and Matale districts. Four organisms were isolated from onion flower: Aspergillus, Penicillium, Collectrotichum and Altenaria. Out of the four, Aspergillus dominated. Hence, Aspergillus sp. isolated from onion flowers was compared with the causative agent of black mold of onion bulbs. Koch's postulation studies of flower and bulb inoculation with respective Aspergillus isolates resulted the same black color molds in the flower and bulb Inoculation of other fungal isolates did not show the black old symptoms in flower and bulb. PCR amplification with ITS1/ITS4 universal primers confirmed the isolated Aspergillus from flower as well as bulb are to be A. niger. Results confirmed that the onion flower black mould disease is caused by $A$. niger: the causal organism of onion bulb black mold as well.
\end{abstract}

Keywords: Aspergillus, Black mold, Flower, Onion, Sri Lanka

\section{Introduction}

Big onion (Allium cepa L.) is considered as a main cash crop grown in dry zone of Sri Lanka. The crop is grown as a bulb crop as well as seed crop. Onion is rich in sugars, vitamins and minerals and hence, it was considered as a valuable dietary nutrient supplement (Ole et al. 2004). Onion crop is highly susceptible to pests and diseases due to its succulent nature. Anthracnose caused by Collectrotichum spp., purple blotch caused by Altenaria spp., fungal bulb rot and bacterial bulb rot are major field diseases observed in onion producing areas of Sri Lanka, while a high incidence of black mold caused by Aspergillus niger results in post-harvest loss after harvesting, storage and during marketing.

Black color mold, caused by Aspergillus niger is the causal agent of onion bulb black mold disease. Among the post-harvest diseases this is the most predominant one and pathogen has a worldwide distribution (Rajam 1992; Wani and Taskeen 2011 and Black et al. 2012). Black mold infection can take place in the field or during storage. The primary symptom of the disease is black discoloration of tissue. Then infected bulbs may show blackening at the neck, streaks or spots of black on or beneath the outer scales, and black discoloration in bruised areas. The entire bulb appears black and shriveled at the final stage (Sinclair and Letham 1996). The fungus needs an 
optimum temperature of $28{ }^{\circ} \mathrm{C}-34{ }^{\circ} \mathrm{C}$ for growth. Warm, moist conditions favor the disease development (Hayden et al. 1994). Black mold can cause 30 to $80 \%$ loss/spoilage of onion (Hayden and Maude 1992; Gupta et al. 2012). Aspergillus niger is a saprophytic and filamentous fungus which is found in soil, organic debris and food products (Mcdonald et al. 2004). The pathogen can be transmitted by infected soil or seed. The infection normally starts at germination of onion seeds and can continue into the storage period (Hayden and Maude 1992; Hayden et al. 1994; Sumner 1995; Koycu and Ozer 1997 and Sirois et al. 1998). A. niger infection to the onion bulb may associated with the production of various enzymes and toxins which reduce the quality and quantity of food products. Also the fungus can establish itself in onion bulb and other tissues (Quadri et al. 1982; Paster et al. 1995; Candlish et al. 2001; Soliman and Badea 2002 and Sibi et al. 2012). Controlling major foliar diseases in onion is problematic particularly in rainy seasons and hence will directly increase the spreading of molds in onion cultivations.

In addition to the black mold disease of onion bulb, it was noted that onion flowers too to suffer from a black mold infection which seems to be spreading in most of the onion growing areas resulting reduction in quality and quantity of onion seeds produced. No records with regard to the onion flower infection by Aspergillus niger could be found so far.

Diseases play a major role in the reduction of worldwide economic crop yield and thereby contributing to loss of farmers' income. For the period of 2001-2003 nearly 16\% yield loss was recorded globally due to plant diseases (Popp and Hantos 2011). Hence proper identification and establishment of disease cycle of emerging and novel diseases is necessary to develop the management strategies and thereby control the spread of such infections.

\section{Materials and Methods}

\section{Isolation of the pathogen}

Big onion flower samples showing mold symptoms from the plants that are free or having very low incidences with other foliar diseases were collected during 2016/17 Maha season from the major onion growing areas of Anuradhapura and Matale districts. Infected flower tissues were cultured on potato dextrose agar (PDA) medium. Isolation of Aspergillus from onion bulbs was done by plating black mold infected outer dry and the inner fleshy scales of the onions on PDA media for the comparison. Cultured plated were incubated at $28{ }^{\circ} \mathrm{C}$ for 6-7 days and single colonies were selected from mixed cultures and purified by sub culturing. Pure cultures were incubated at $28{ }^{\circ} \mathrm{C}$ for 6-7 days and maintained on PDA slants for further use.

\section{Morphological identification}

Morphological observations were done for the morphologically different purified cultures. Slide culture technique was practiced specially for separation of pathogens which cannot be identified using the shape of the spores under the light microscope (Olympus CX41).

\section{Confirmation of pathogenecity}

Koch's postulation was conducted for pathological confirmation of the disease causing fungus. Flower inoculation was done with the four fungi isolated from flower and the Aspergillus sp. isolated from bulb, separately. This was conducted as a pot experiment during 2017 Yala season. Flower crops were maintained in a manner similar to the healthy crop before inoculation. Afterwards, inoculated crop was covered separately to avoid cross contamination. Bulb inoculation was done with the isolated Aspergillus and Penicillum from flower and Aspergillus isolated from bulb, separately. Uniform sized, fresh, healthy onion bulbs were collected. The bulbs were thoroughly washed in tap water, then surface sterilized by dipping in 1 per cent $\mathrm{NaOCl}$ (Sodium hypochlorite) solution for one minute followed by three successive washings with sterile distilled water. The spores were harvested from a seven day old culture grown on PDA medium. Then the bulbs were inoculated with 
the pathogen spore suspension $\left(1.5 \times 10^{8} \mathrm{CFU} / \mathrm{ml}\right)$ using sterilized needle streaking. Inoculated bulbs were kept in plastic humidity boxes separately while maintaining the humidity by spraying distilled water daily. The bulbs were observed daily for symptom expression. The bulbs showing typical disease symptoms were used for reisolation of the pathogen for the morphological confirmation.

\section{Confirmation of identity}

Luria broth culture was prepared in a $250 \mathrm{ml}$ conical flask and mycelia disks taken from 7 days old actively growing fungal cultures were placed in Luria broth. Inoculated flasks were incubated in an orbital shaker at 30 rpm for 7 days at room temperature. Total genomic DNA was extracted from the 7 day old broth cultured mycelia using Cetrimide Tetradecyl Trimethyl Ammonium Bromide (CTAB) extraction method (Rajapakse et al. 2016). PCR amplification was done for the samples with the universal primers; ITS -1 (Forward): 5'TCCGTAGGTGAACCTGCGG-3' and ITS-4 (Reverse):5'TCCTCCGCTTATTGATATGC - 3' (White et al. 1990).

PCR amplifications were performed in a total volume of $10 \mu \mathrm{l}$ by mixing $1 \mu 1$ of the template DNA with $0.5 \mu 1$ of each primer, $0.5 \mu \mathrm{l}$ of dNTP and $0.2 \mu \mathrm{l}$ of Taq DNA polymerase, $2 \mu \mathrm{l}$ of 5x PCR Buffer with loading die, $0.8 \mu 1$ of $\mathrm{Mgcl}_{2}$ and $4.5 \mu \mathrm{l}$ of sterilized distilled water. These reactions were subjected to an initial denaturation of $5 \mathrm{~min}$ at $94{ }^{\circ} \mathrm{C}$, followed by 35 cycles of $1 \mathrm{~min}$ at $94{ }^{\circ} \mathrm{C}, 1 \mathrm{~min}$ at $50{ }^{\circ} \mathrm{C}$, and $1 \mathrm{~min}$ at $72{ }^{\circ} \mathrm{C}$, with a final extension of 10 min at $72{ }^{\circ} \mathrm{C}$ followed by termination of the cycle at $4{ }^{\circ} \mathrm{C}$ in an Applied Bio Systems Verity machine. Amplified product aliquots $(5 \mu \mathrm{l})$ were analyzed by electrophoresis in $1.2 \%(\mathrm{wt} / \mathrm{vol})$ agarose gel in $1 \mathrm{X}$ TAE buffer stained with ethidium bromide, and photographed over a UV transilluminator. Promega 100bp ladder was used as a marker.

PCR products of the samples were sequenced (by Macrogen, Korea) and FASTA form of the result sequences were edited and analyzed according to the NCBI (National Center for Biotechnology Information) Basic Local Alignment Search Tool (BLAST).

\section{Results and Discussion}

\section{Isolation and identification of the pathogen}

Mold symptoms of the onion flower was observed during Maha season, the major season for the onion seed production. Black color mold was observed on onion florets at the centre and later spreading to the whole inflorescence (Figure 1).

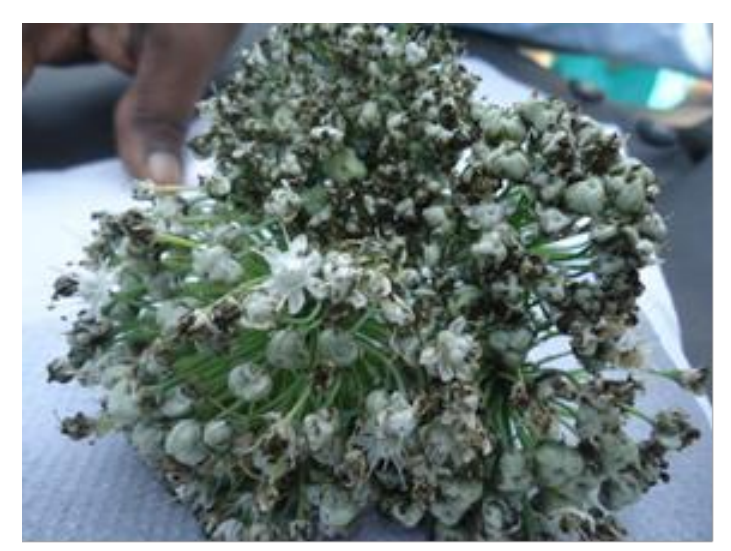

Figure1. Onion flower showing black mold symptoms 
This results in low seed setting together with inferior quality of seeds i.e. shriveled and small seeds. Other fungal and bacterial diseases also become very prominent during this season due high rainfall received in onion cultivating areas. Hence, collection of samples free from other infections was of utmost importance. However, most of the samples collected were visually free from other foliar fungal infections but may have had latent infections. Therefore, most of the cultured samples from moldy flowers resulted mix cultures yet Aspergillus growth was very prominent compared with the other isolates. In certain cases, pure growth of Aspergillus was obtained. Mainly four isolates were resulted from mix cultures. They are: (i) Aspergillus sp. (Figure 2), causal organism of onion bulb black mold, (ii) Penicillium sp., causal organism of onion bulb blue mold rot, (iii) Collectrotichum sp., causal organism of anthracnose and (iv) Altenaria sp., causal organism of purple blotch disease of onion.
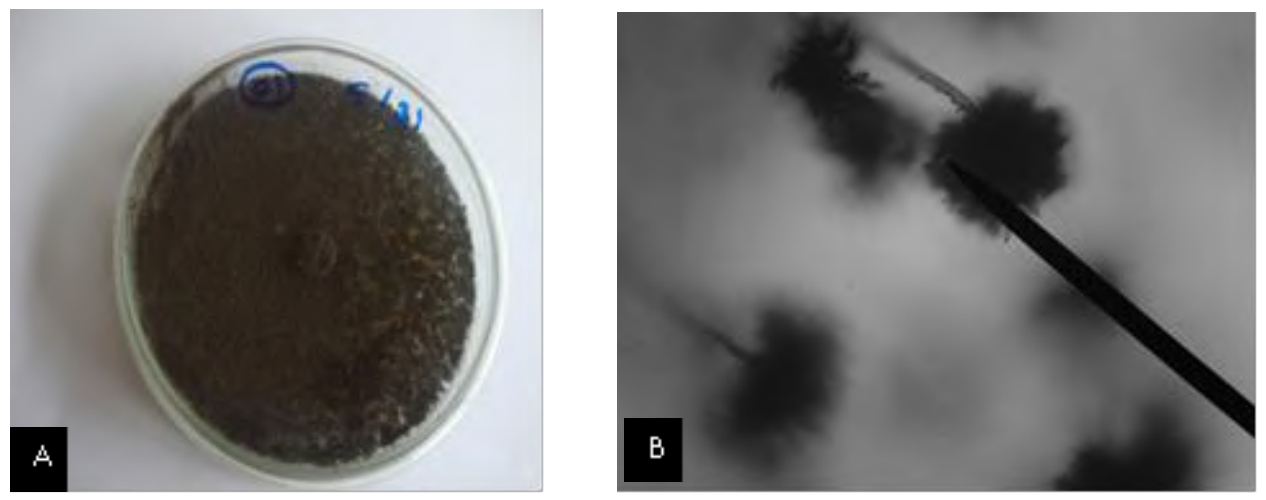

Figure 2. A-Purified Aspergillus isolated from flower; B, A view of Aspergillus conidiophores under light microscope (X200)

Colony colour of the isolated fungal mycelium was initially white which turned black with conidial production. Reverse side was pale yellow. The mycelium was septate. Conidiophores arise from the mycelium. Conidia were brown to black in colour and were globose in shape. Conidia formed densely over the center (Figure 2).

\section{Confirmation of pathogenicity}

Koch's postulation results indicated that the inoculation of Aspergillus sp. isolated from both the flower and bulb produced similar symptoms of black color mold growth of onion flower as observed in farmer field. Koycu and Ozer (1997) explained that visual symptoms are not observed on sets developing from A. niger infected seeds because of the latent infection. Visible external and internal symptoms can be observed only in infected consumable product (Sumner 1995; Sinclair and Letham 1996). But according to El-Nagerabi et al. (2016) 89$100 \%$ of collected seed samples of the onion cultivars were highly contaminated by A. niger showing low levels of seed germination, too (39-83\%). This is due to latent infection by A. niger. But in Sri Lankan field and laboratory results revealed that clear visible external symptoms of black mold can be observed in onion flower from the very beginning of floret opening to the seed setting.

Bulb inoculation results similarly produced onion bulb black mold symptoms from both Aspergillus spp. isolated from flower and bulb. The bulbs expressed the symptoms 6-7 days after inoculation (Figure 3). 

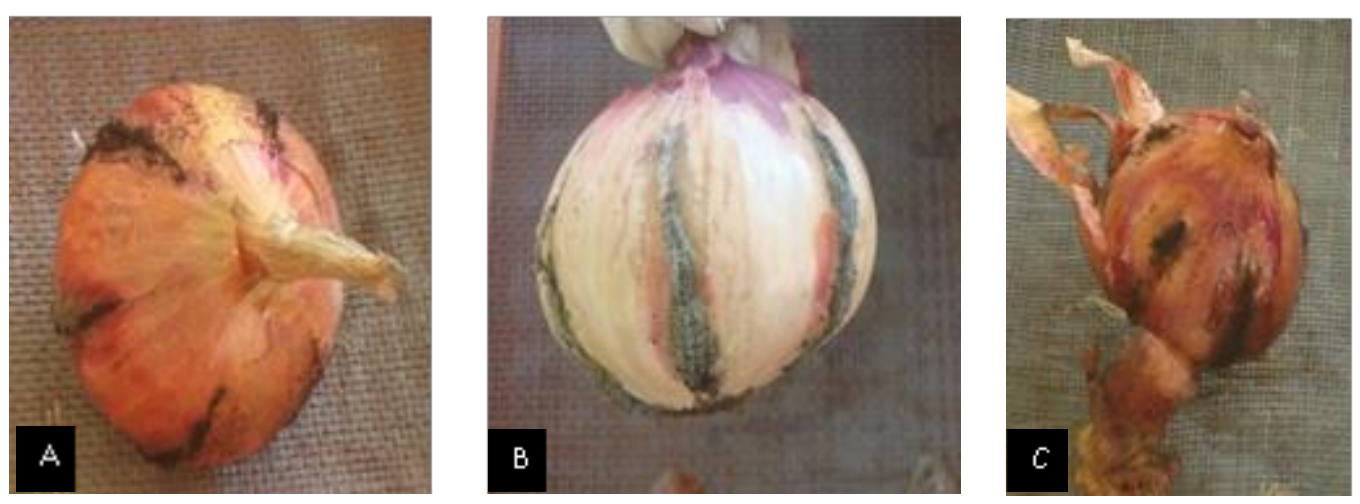

Figure3. Bulb inoculation. A- Aspergillus isolated from flower; B-Penicillium isolated from flower; $C$ Aspergillus isolated from bulb

The bulbs produced initially whitish thin mycelia over the inoculated area. Then clusters of black spores produced along veins and between the outer scales of bulbs. Finally, the whole bulbs were covered with black spores with the infection spreading.

Penicillum sp. inoculation to the onion bulb did not show the black mold symptoms and expressed the symptoms of pale yellowish lesions and watery soft spots covered with characteristic blue-green spores which are the symptoms of blue mold in onion (Black et al. 2012).

Flower inoculation of Penicillum sp. also did not show black color mold growth. Instead growth of off green color mycelium was observed.

Flower inoculation with Collectrotichum and Altenaria spp. resulted the drying up of florets with no seed production which are the typical flower symptoms of Anthracnose and purple blotch (Gunewardana et al. 2015).

\section{Confirmation of identity of the pathogen}

Described morphological characters are not enough to identify the Aspergillus isolates since most of the isolates have similar morphological characters. Hence, there is a need to use molecular tools to overcome the limitations of morphological characterization. Development of molecular techniques and the use of DNA sequencing became a new era in fungal identification (Samuels 2006).

Amplification of the DNA region of the Aspergillus isolate with ITS1 and ITS4 primers yielded products of approximately $575 \mathrm{bp}$ as estimated by agarose gel electrophoresis in both Aspergillus spp. isolated from flower and bulb (Figure 4). 


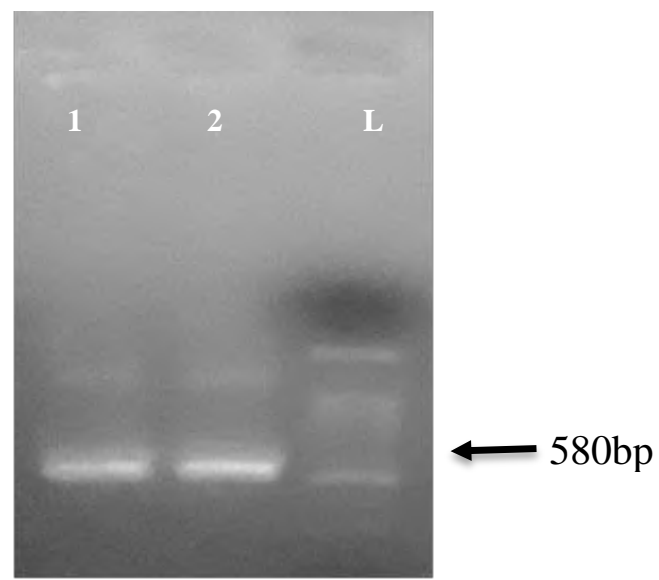

Figure 4. PCR amplification of the DNA from the Aspergillus isolates with ITS1 and ITS4. lane 1-Aspergillus spp. isolated from onion bulb; lane 2-Aspergillus spp. isolated from onion flower; Lane L-100bp ladder

The ITS sequences for the fungi were analyzed by BLAST analysis which revealed the identity of each predominant fungus. Both Aspergillus spp. were identified as A. niger with $98 \%$ nucleotide similarity. Therefore, morphological identification combined with molecular analysis confirmed Aspergillus niger as the causative organism of flower black mold disease of big onion which is responsible for the reduction of seed yield and quality of seeds produced. This is the first report worldwide that establishes A. niger as the infectious agent of big onion flower black mold disease. Future research should be conducted to identify the pre and post treatments to control the infection and spreading of the disease among cultivations

\section{Conclusion}

Based on the morphological and molecular studies, black mold symptoms in onion flower were caused by $A$. niger, the same pathogen that causes onion bulb black mold disease.

\section{Acknowledgement}

The authors wish to express their thanks to Sri Lanka Council for Agricultural Research Policy for funding this study under NARP. Sincere thanks also go to the Extension Officers of the DOA for extending support in sample collection.

\section{References}

Black, L., Conn, K., Gabor, B., Kao, J., and Lutton, J., 2012, Onion disease guide. A practical guide for seedsmen, growers and Agricultural Advisors (Seminis Plant Health, USA).

Candlish, A.A.G., Pearson, S.M., Aidoo, K.E., Smith J.E., Kell, B., and Irvine, H., 2001, A survey of ethnic foods for microbial quality and aflatoxin content. Food Addit Contaminants, 18:129-136.

El-Nagerabi, S.A.F., Ahmed, A.H.M., Elshafie, A.E., 2016, In vitro evaluation of selected plant extracts as biocontrol agents against black mold (Aspergillus niger Van Tieghem) of onion bulbs (Allium cepa L.). Science and Technology, 5 (1): 147-152.

Gunawardana, K.N.C., Fernando, W.M.K., Fernando, H.N.S., and Renuka, K.A., 2015, Technical bulletin on pest, disease and nutrient disorders identification of other field crops (Department of Agriculture, Sri Lanka).

Gupta, R., Khokhar, M.K., and Lal, R., 2012, Management of the Black Mould Disease of Onion. Indian Journal of plant pathology and micro biology, 3:133. 
Hayden, N.J., and Maude, R.B., 1992, the role of seed-borne Aspergillus niger in transmission of black mould of onion. Plant Pathology, 41: 573-581.

Hayden, N.J., Maude, R.B., Proctor, F.J., 1994, Studies on the biology of black mold (Aspergillus niger) on temperate and tropical onions- A comparison of sources of the disease in temperate and tropical field crops. Plant Pathology, 43: 562-569.

Koycu, N.D., and Ozer, N., 1997, Determination of seed borne fungi in onion and their transmission to onion set. Phytoparasitica, 25: 25-31.

McDonald, M.R., Jaime, M.A., and Hovius, M.H.Y., 2004, Management of diseases of onions and garlic. In Diseases of fruits and vegetables. eds. Naqvi, S.A.M.H. Kluwer (Academic Publishers. The Netherlands). 2:149200.

Ole, H., Torben L., Lars, P.C., Ulla, K., Nazmul, H., and Shakuntala, H.A., 2004, Contents of Iron Zinc, and $\beta$ ca-rotene in commonly consumed vegetables in Bangladesh. Journal of Food Composition and Analysis, 17: $587-$ 595.

Paster, N., Menasherov, M., Ravid, U., and Juven, B., 1995, Antifungal activity of oregano and thyme essential oils applied as fumigants against fungi attacking stored grain. Journal of Food protects, 58:81-85.

Popp, J., and Hantos, K., 2011. The impact of crop protection on agricultural production, Studies in Agricultural Economics, Research Institute of Agricultural Economics, Budapest, Hungary, pp. 47-66.

Quadri, S.M.H., Srivastava, K.J., Bhonde, S. R., Pandey, U.B., and Bhagchandani, P.M., 1982. Fungicidal bioassay against certain important pathogens of onion, Pesticides, 16: 11-16.

Rajam, S.R., 1992. Studies on the post-harvest fungal spoilage of onion. M. Sc. Ag.) Thesis (Unpublished), Tamil Nadu Agricultural University, Coimbatore.

Rajapakse, R.G.A.S., Fariz, F.S., Wickramarachchi,.W.A.R.T, Dissanayake, D.M.K.K. Premarathne, M.P.T., and Kahawatte, K.J.P.K., 2016, Morphological and molecular characterization of Trichoderma isolates used as bio control agents in Sri Lanka. Tropical Agriculturists, Vol. 164.

Sibi, G., Awasthi, S., Dhananjaya, K., Mallesha, H., and Ravikumar, K.R., 2012, Comparative studies of Plumeria species for their phyto-chemical and antifungal properties against Citrus sinensis pathogens. Int J Agri Res, 7(6): 324-331.

Sinclair, P.J., and Letham, D.B., 1996, Incidence and sites of visible infection of Aspergillus niger on bulbs of two onion (Allium cepa) cultivars. Australian Plant Pathology, 25: 8- 11.

Sinclair, P.J., and Letham, D.B., 1996, Incidence and sites of visible infection of Aspergillus niger on bulbs of two onion (Allium cepa) cultivars. Australasian Plant Pathology, 25: 8-11.

Sirois, K..L., LoParco, D.P., and Lorbeer, J.W., 1998. Development of a bioassay to determine the presence of specified fungal pathogen of onion. In: Proceedings of the $7^{\text {th }}$ Biennial National Onion (and Other Allium) Research Conference, California, 10-12 December 1998, pp. 231-237.

Soliman, K.M., and Badea, R.I., 2002, Effect of oil extracted from some medicinal plants on different mycotoxigenic fungi. Food Chem. Toxicology, 40: 1669-1675. 
Sumner, D.R., 1995. Diseases of bulbs caused by fungi -Black mold. Schwartz, F. and Mohan, S.K.. eds. Compendium of onion and garlic disease (APS press. St. Paul, Minn.). pp 26-27.

Tysoni, J.L., and Fullerton, R.A., 2004, Effect of soil borne inoculums on incidence of onion black mold (Aspergillus niger). New Zealand Plant Protection, 57: 138-141.

Wani, A.H., and Taskeen., 2011, Management of black mold rot of onion. Mycopathology, 9: 43-49.

White, T.J., Bruns, T., Lee, S., and Taylor, J.W., 1990. Amplification and direct sequencing of fungal ribosomal RNA genes for phylogenetics. In: Innis, M.A., Gefand, D.H., Sninsky, J.J. and White, T.J. (Eds.), PCR Protocols: A Guide to Methods and Applications (Academic press, New York). pp. 315-322. 